\title{
Benchmark Analysis of VVER-1000 Nuclear Reactor using MCNPX code for the Westinghouse and the TVEL Fuel Assemblies
}

\author{
Afaf A.E. Ateya \\ Department of Operation Safety and Human Factors \\ Nuclear and Radiological Regulatory Authority, \\ 3 Ahmed El-Zomor Street, El-Zohour Region, Nasr City-Cairo
}

Egypt

\begin{abstract}
The computational benchmarks performed on the TVEL and the Westinghouse fuel assemblies for the VVER-1000 nuclear power reactor have been calculated by the Monte Carlo code (version MCNPX 2.7). The calculations were performed on models of the fuel assemblies of the VVER-1000 reactor. The basis was taken of a typical fuel assembly of the Russian TVEL suppliers and the new fuel assemblies of the American company Westinghouse. The aim of this work was to analyze the changes in the isotopic composition of spent nuclear fuel of VVER-1000 due to various operational conditions. The variations of $k_{\text {eff }}$ and assembly's average isotopic composition vs. burnup were calculated. Fission and activation products and actinide daughter nuclides selected for calculation e.g. ${ }^{235} \mathrm{U},{ }^{236} \mathrm{U},{ }^{239} \mathrm{Pu},{ }^{154} \mathrm{Eu},{ }^{134} \mathrm{Cs}$, were those important for the assessment of nuclear safety in the management and storage of spent fuel. The variations of isotopic composition vs. time during operation and cooling were calculated. Most of the results agreed excellently with those calculated by the SERPENT code.
\end{abstract}

Keywords: Water-Water Energetic Reactor, Fuel Assembly, Westinghouse, Russian TVEL, Burnup Calculation, Mcnpx Code

\section{INTRODUCTION}

The neutronic calculations for power reactors are one of the most important steps for reactor safety. VVER (Water-Water Energetic Reactor) is one of the most successful and influential branches of nuclear power plant development, and the technology is widely distributed throughout the world. Several benchmark exercises have been proposed by an international experts group at the OECD/NEA with the intent to investigate the core physics behavior of a VVER-1000 reactor loaded with 2/3rd of (LEU) fuel assemblies and 1/3rd of (MOX) fuel assemblies [1]. The group studied the changes in isotopic composition of spent fuel of VVER-1000 due to changes in operating conditions e.g. moderator water density and fuel temperature were calculated by SERPENT code [3]. They used SCALE code to analyze the impact on VVER-1000 spent fuel isotopic composition caused by different operational conditions [4]. Calculations were carried out for fuel assemblies for VVER-1000, the typical fuel assemblies of Russian TVEL suppliers, and for the new fuel assemblies of Westinghouse Company. Spent nuclear fuel with the same burnup value can have different isotope composition depending on neutron spectrum in which this burnup took place.

The current work has analyzed the changes in isotopic composition of VVER-1000 spent fuel caused by different operational conditions, such as the presence or absence of absorber-rods in an assembly, oscillating the concentration of boric acid. Calculations were made for fuel assemblies of VVER-1000 including assemblies with maximum multiplying purpose (enrichment of $4.4 \%$ ) arranged with pitch of $23.6 \mathrm{~cm}$. Concentration as function of burnup of ten isotopes which are the most usable in "burnup credit" methodology, such as the main fuel isotopes ${ }^{235} \mathrm{U},{ }^{236} \mathrm{U},{ }^{238} \mathrm{U},{ }^{239} \mathrm{Pu},{ }^{240} \mathrm{Pu},{ }^{241} \mathrm{Pu}$, as well as some actinides, and fission products, such as ${ }^{242} \mathrm{Pu},{ }^{241} \mathrm{Am},{ }^{149} \mathrm{Sm},{ }^{151} \mathrm{Sm}$ was analyzed. All the calculations were performed by the reactor cell burnup code NESSEL developed by the company K.A.B. GmbH, Germany, for calculating VVER reactor fuel cell. NESSEL calculations are performed in 34 neutron energy group model (24 epithermal, 10 thermal) [5].

In this work, the changes in isotopic composition of spent fuel VVER-1000, due to various operating conditions such as concentration of boric acid dissolved in the moderator, water density, and fuel temperature were calculated. Operational parameters that were used when performing isotope composition calculation are listed in table 1. 
Table 1: Operational parameters that were used when performing isotope composition calculation

\begin{tabular}{|l|l|}
\hline Parameters & Av. \\
\hline Enrichment (wt\%) & FA - A: 306*4.4\%+6*3.6\% (BA) \\
& $\begin{array}{l}\text { FA -WR:240*4.2\%+60*3.9\%+6*3.6\%+ } \\
6 * 3.0 \%(B A)\end{array}$ \\
\hline Weight fuel (kg / FA) & FA -A: 497.9, FA -WR: 552.8 \\
\hline Concentration Boric acid (ppm) & 525 \\
\hline Water density (g/ cm3) & 0.72 \\
\hline Water temp. $(\mathrm{Grad} \mathrm{K})$ & 600 \\
\hline Fuel temp. $(\mathrm{Grad} \mathrm{K})$ & 1050 \\
\hline
\end{tabular}

This work analyzed the changes in concentration as function of burnup of fuel assemblies of TVEL and the Westinghouse fuel assemblies for VVER-1000 nuclear power reactor using Monte Carlo code (version MCNPX 2.7). The variations of $\mathrm{k}_{\mathrm{eff}}$ and assembly average isotopic composition versus burnup were calculated. The fission and activation products, and actinide daughter nuclides selected for the calculation were: ${ }^{236} \mathrm{U},{ }^{236} \mathrm{U},{ }^{239} \mathrm{Pu},{ }^{154} \mathrm{Eu},{ }^{134} \mathrm{Cs}$ since these isotopes are important for the assessment of nuclear safety and in the management and storage of spent fuel.

\section{BENCHMARK MODELS SPECIFICATIONS}

The benchmark model consists of two different assembly types of the advanced Russian designs of the VVER-1000 reactor viz. FA-A manufactured by the Russian company TVEL, and FA-WR manufactured by the US Westinghouse company. Parameters of the fuel assemblies FA-A and FA-WR are shown in table 2. Figures 1 and 2 present images of the FA-A and FA-WR from VISED of MCNPX code. Figure 3 presents a fuel cell model of FA-A, FA-WR showing the central tube and guide tube [3-4]. The VVER-1000 is hexagonal in shape having 163 hexagonal fuel assemblies. Each assembly consists of one central tube, 312 fuel pin locations (rods) of different enrichment (as shown in table 2), and 18 guide tubes. See figure 1. The clad and structural materials were composed of Zr-Nb alloys. Fuel pin lattice pitch was $12.75 \mathrm{~mm}$, and pitch between fuel assemblies was $23.6 \mathrm{~cm}$.

Table 2. The main differences in geometrical and material parameters of TVS-A and FA-WR

\begin{tabular}{|c|c|c|}
\hline Parameter & TVS-A (TVEL) & FA-WR (Westinghouse) \\
\hline Fuel stack length (mm) & 3530 & 3530 \\
\hline Central Zone length (nom.)(mm) & 3530 & 3225.2 \\
\hline Axial Blanket length (nom.) & - & 2 zone x $152.4 \mathrm{~mm}$ \\
\hline Fuel mass $\left(\mathrm{UO}_{2}\right)(\mathrm{kg})$ & $497.9 \pm 4.8$ & $552.8 \pm 5.3$ \\
\hline \multicolumn{3}{|l|}{ Fuel pin (312 pieces/FA) } \\
\hline Enrichment (wt\%) & $\begin{array}{l}306 * 4.4 \%+ \\
6 * 3.6 \%(\mathrm{BA})\end{array}$ & $\begin{array}{l}240 * 4.2 \%+60 * 3.9 \%+6 * 3.6 \%+ \\
6 * 3.0 \%(\mathrm{BA})\end{array}$ \\
\hline Pellet ID/OD (mm) & $1.4 / 7.57$ & $-/ 7.84$ \\
\hline Cladding ID/OD (mm) & $7.73 / 9.1$ & $8.0 / 9.14$ \\
\hline Cladding material/ density (g/cm3) & alloy Э110 / 6.45 & alloy ZIRLOTM / 6.55 \\
\hline \multicolumn{3}{|l|}{ Central tube } \\
\hline ID/OD, mm & $11.0 / 13.0$ & $11.0 / 12.6$ \\
\hline Material / density (g/cm3) & alloy Э635 / 6.45 & alloy ZIRLOTM / 6.55 \\
\hline \multicolumn{3}{|l|}{ Guide tube (18 pieces) } \\
\hline ID/OD (mm) & $10.9 / 12.6$ & $11.0 / 12.6$ \\
\hline Material & alloy Э635 / 6.45 & alloy ZIRLOTM / 6.55 \\
\hline
\end{tabular}




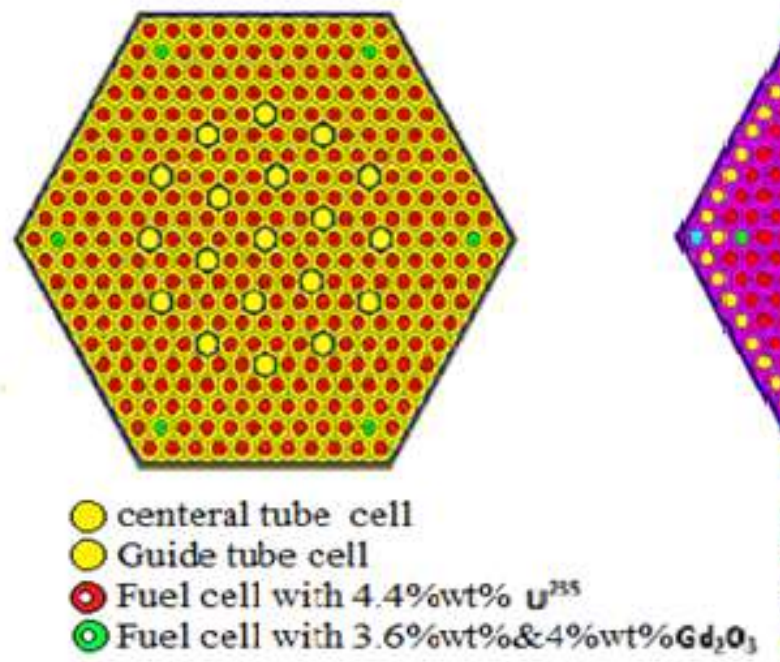

Fig. 1 Model of the FA-A of MCNPX code

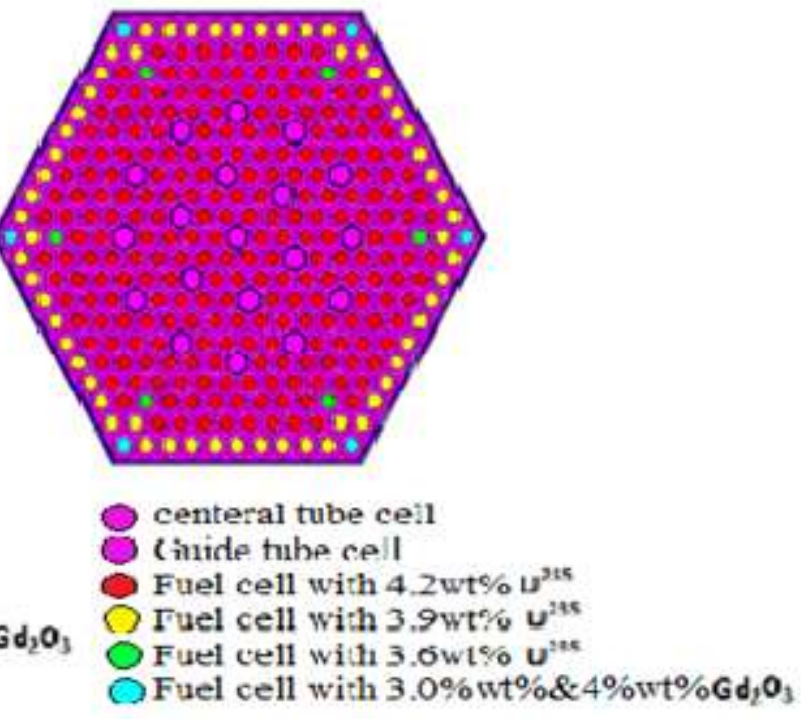

Fig. 2 Model of FA-WR of MCNPX code
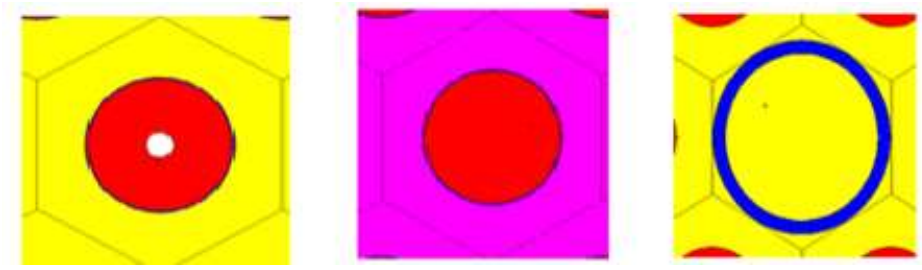

Fig.3 Model of FA-A fuel cell,FA-WR fuel cell and central tube cell of MCNPX code

\section{CALCULATION METHOD}

This paper describes the results of a benchmark study investigating the physics of the VVER-1000 reactor FA-A, and FA-WR fuel assemblies. Calculations were performed with MCNPX code (version MCNPX 2.7). Calculations included the variation of $\mathrm{k}_{\mathrm{eff}}$ with burnup for FA-A, and FA-WR fuel assemblies. Also, isotopic composition of the spent fuel assemblies of VVER-1000 were tallied. The fission and activation products, and actinide daughter nuclides selected for the calculation were: $\mathrm{U}^{235}, \mathrm{U}^{236}, \mathrm{Pu}^{239}$, all other Pu isotopes, Europium-154 (Eu $\left.{ }^{154}\right)$, Caesium -134 $\left(\mathrm{Cs}^{134}\right)$ and all other Caesium isotopes. The irradiation history was defined in units of time or burnup.

Each calculation Monte Carlo used 5000 neutrons per cycle, including 20 inactive cycles to converge the source, and 480 active cycles. The calculations were performed on models of the fuel assemblies of VVER-1000 at burnup level of 50 (MW.Day/kgHM) in four-years fuel cycle. These models are based on a typical modern fuel Assembly FA-A of Russian TVEL suppliers and new fuel assemblies FA-WR of Westinghouse company.

\section{RESULTS AND DISCUSSION}

The present work compared the results of MCNPX calculations on the two models, viz. FA-A, and FA-WR fuel assemblies, in comparison to the results of SERPENT code calculations on the two models carried out by Kovbasenko et al. [5] through 1400 day, up to $50 \mathrm{MW}$.day/kgHm burnup.

\subsection{The Variation of Effective multiplication factor with Burnup}

Figure 4 and table 3 present the results of neutron multiplication factor $\mathrm{k}_{\mathrm{eff}}$ calculations vs. burnup for average operating conditions, see table 1. Figure 4 also shows a comparison between $\mathrm{k}_{\text {eff }}$ calculations on the two models using MCNPX and benchmark calculations on both models using SERPENT code [5].

It was found that for FA-A assembly, as the burnup increases the $\mathrm{k}_{\mathrm{eff}}$ initially increased due to the rapid burn out of Gd isotopes, and buildup of Pu-239. While for FA-WR assembly, burn up of Pu-239 was not compensated by the burn up of gadolinium isotopes hence, $\mathrm{k}_{\mathrm{eff}}$ decreased rapidly till complete burnup of gadolinium. 
Westinghouse FA-WR had lower value of the neutron multiplication factor $\mathrm{k}_{\text {eff }}$ compared to FA-A company TVEL. Obviously, this is due to the lower average enrichment of FA-WR fuel. It is also noticeable that the difference between the two values in the first three years was constant (approximately $0.022 \mathrm{pcm}$ ).

Table 3. Comparison of change of $k_{\text {eff }}$ vs. burnup for FA-A and FA-WR

\begin{tabular}{|c|c|c|c|c|c|c|}
\hline \multirow{2}{*}{$\begin{array}{l}\text { burnup } \\
\mathrm{MWD/} \\
\mathrm{kgU}\end{array}$} & \multicolumn{3}{|c|}{ MCNPX calculations } & \multicolumn{3}{|c|}{ SERPENT calculations (ref.) } \\
\hline & $\begin{array}{l}\mathbf{k}_{\text {eff }}(\mathbf{F A}-\mathrm{A}) \\
\text { Error }=0.00039 \%\end{array}$ & $\begin{array}{l}\mathbf{k}_{\text {eff }}(\mathbf{F A}-\mathbf{W R}) \\
\text { Error }=0.00039 \%\end{array}$ & $\Delta \mathbf{k}_{\text {eff }}$ & $\begin{array}{l}\mathbf{k}_{\text {eff }} \quad(\mathrm{FA}-\mathrm{A}) \\
\text { Error=0.0004\% }\end{array}$ & $\begin{array}{l}k_{\text {eff }} \quad(\text { FA-WR }) \\
\text { Error }=0.0004 \%\end{array}$ & $\Delta \mathbf{k}_{\text {eff }}$ \\
\hline 0 & 1.35162 & 1.32445 & 0.02717 & 1.33 & 1.32 & 0.013 \\
\hline 10 & 1.25587 & 1.231289 & 0.024581 & 1.18 & 1.16 & 0.016 \\
\hline 20 & 1.166946 & 1.143377 & 0.023569 & 1.09 & 1.07 & $\overline{0.016}$ \\
\hline 30 & 1.084095 & 1.058502 & 0.025593 & 1.02 & 1.00 & 0.01 \\
\hline 40 & 1.0002313 & 0.979699 & 0.0205323 & 0.95 & 0.94 & 0.01 \\
\hline 50 & 0.9256217 & 0.911307 & 0.0143147 & 0.887 & 0.882 & 0.005 \\
\hline
\end{tabular}

Table 4. Percent difference between MCNPX and SERPENT calculated $k_{\text {eff }}$ vs. burnup for FA-A and FA-WR.

\begin{tabular}{|c|c|c|}
\hline \multirow[t]{2}{*}{$\begin{array}{l}\text { Burnup } \\
\text { MWD/kgU }\end{array}$} & \multicolumn{2}{|c|}{$\frac{k_{e f f}(M C N P X)-k_{e f f}(S E R P E N T)}{k_{e f f}(S E R P E N T)} \%$} \\
\hline & FA-A & FA-WR \\
\hline 0 & 1.62556 & 0.33712 \\
\hline 10 & 6.42966 & 6.1456 \\
\hline 20 & 7.05927 & 6.85766 \\
\hline 30 & 6.28382 & 5.8502 \\
\hline 40 & 5.28751 & 4.2233 \\
\hline 50 & 4.35419 & 3.32279 \\
\hline
\end{tabular}

Tables 3 and 4 show that for fresh fuel (before burnup) for both FA-A and FA-WR models, the calculated $k_{\text {eff }}$ values were very close for calculations using MCNPX code (our work) and using SERPENT code [5]. However, as burnup proceeded, the two codes yielded significantly different values of $\mathrm{k}_{\text {eff }}$. For both models, MCNPX estimated $\mathrm{k}_{\text {eff }}$ were higher than those estimated by SERPENT code. Difference was within 5.2\% On the average. Though such difference is accepted in MCNPX as statistical variation, however, in nuclear reactor physics, such (though low) difference, is too large from reactor reactivity point of view.

Such discrepancy between the two codes on burnup, may be due to difference in cross sectional libraries, and/or difference in fission product inventory in both codes. 


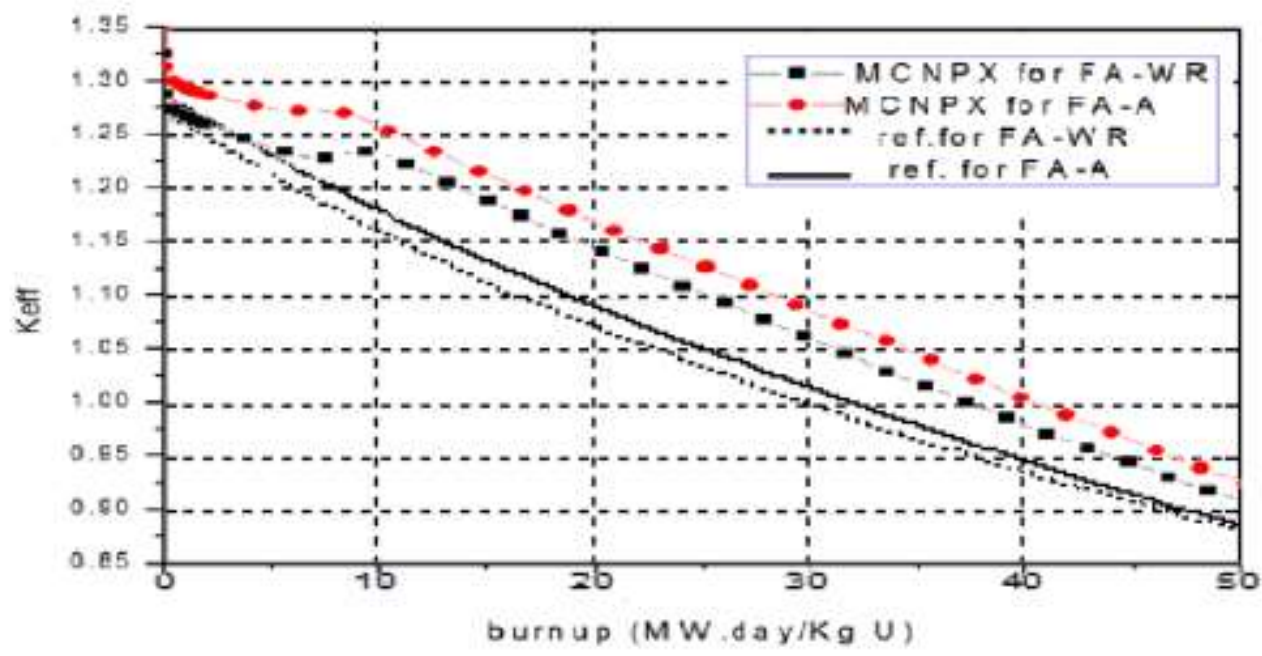

Fig. $4 \mathbf{k}_{\text {eff }}$ vs. burnup for FA-A and FA-WR assemblies

Figure 4 shows that at the same burnup, spent FA-WR (Westinghouse) had less $\mathrm{k}_{\text {eff }}$ than the TVS-A (TVEL). This means that there are additional safety margins in normal and emergency operating conditions. $\mathrm{k}_{\mathrm{eff}}$ for spent FA-WR (Westinghouse) was less by $\sim 1 \%$ than that for FA-A.

\subsection{Variation of Isotopes concentration in Assemblies with Burnup:}

Concentration of the $\mathrm{U}, \mathrm{Pu}, \mathrm{Cs}$, and Eu isotopes were calculated using MCNPX code with burnup up to 50MW.day/kgHM, and during cooling after discharge from reactor. The obtained results were compared to the results published in the paper [3,4], see figures 5-11 and tables 3-4.

The concentrations of the isotopes which is presented in table 3 were calculated at the moment of the discharge fuel from the core of reactor (up to burnup of $50 \mathrm{MW}$.day/kg HM). Figures 5-12 present the concentration of the main fuel isotopes viz. $\mathrm{U}^{235}$, $\mathrm{U}^{236}$ and $\mathrm{Pu}^{239}$, which are important for the assessment of nuclear safety, and in the management and storage of spent fuel.

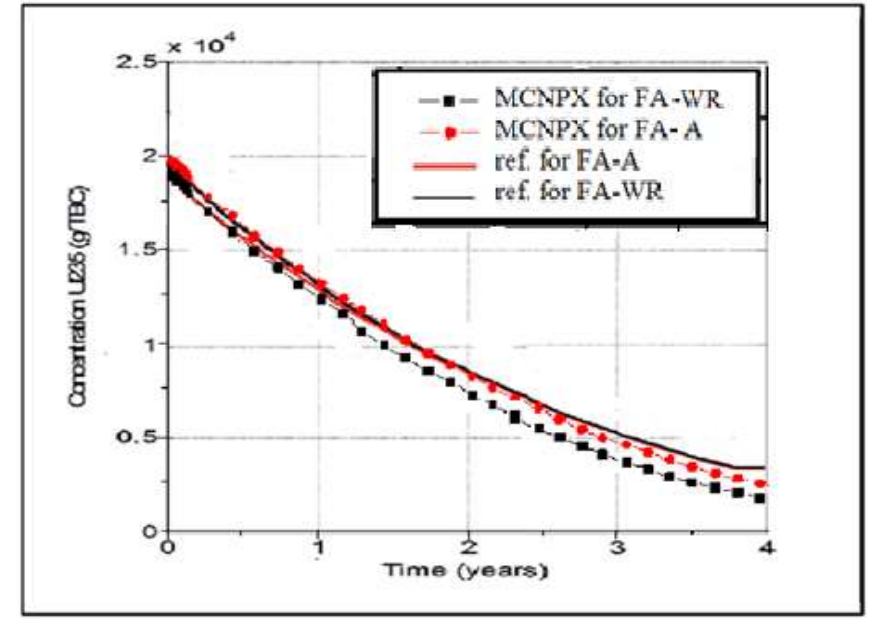

Figure 5: The mass of $U^{235}$ during operation 


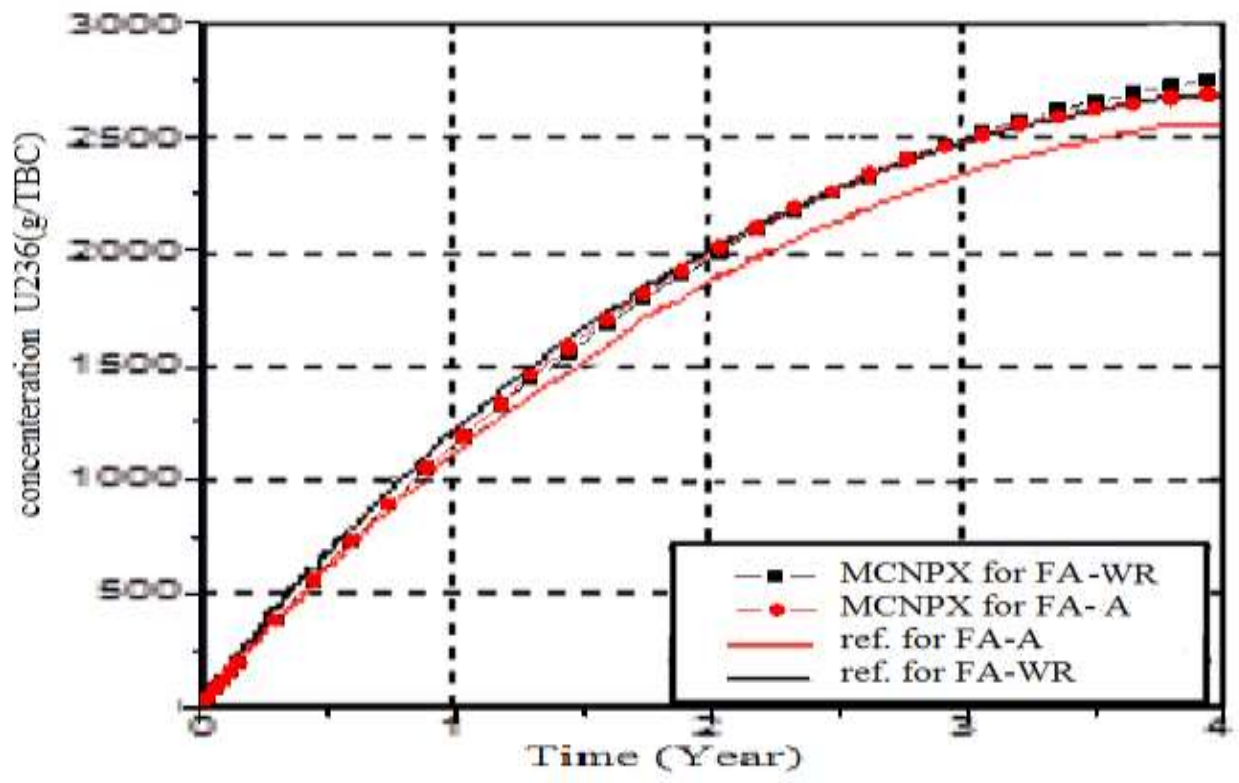

Figure 6: The mass of $U^{236}$ during operation

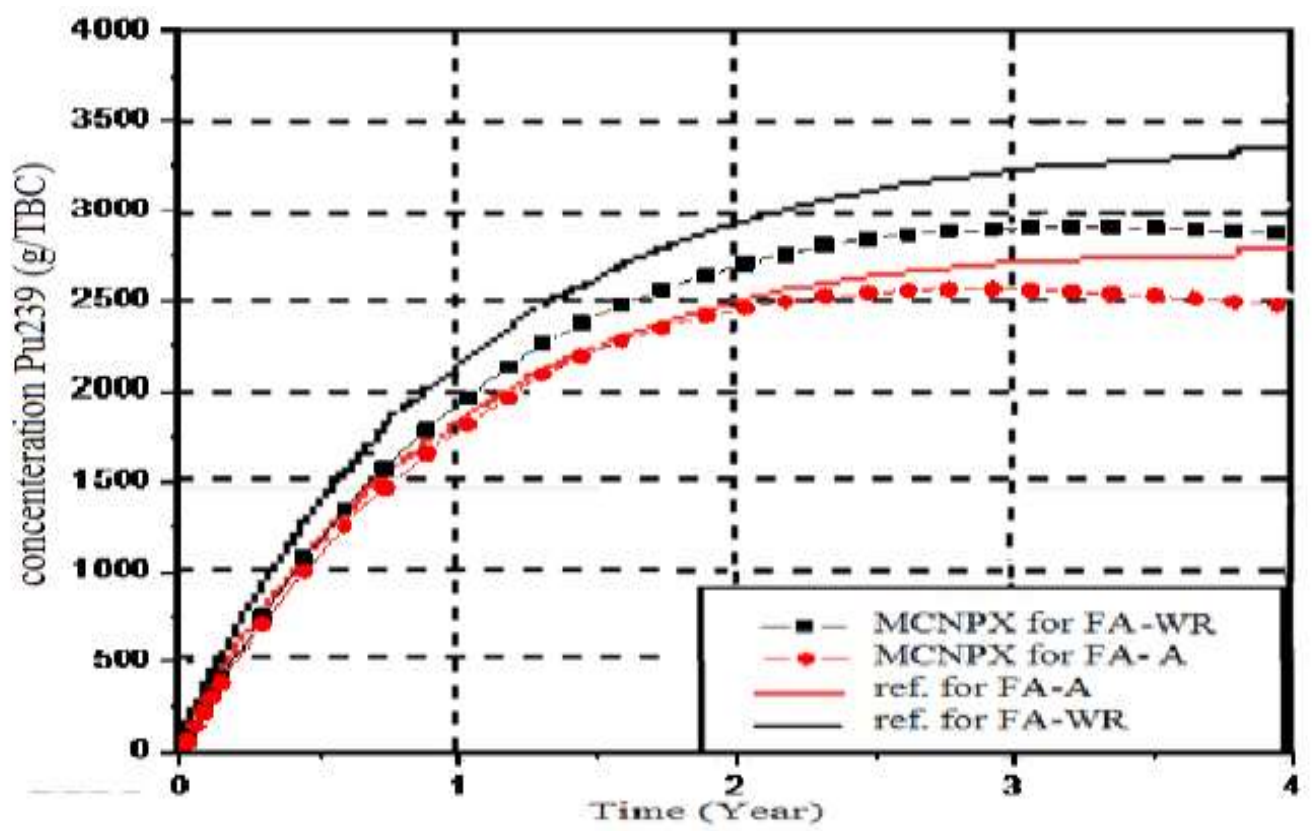

Figure 7: The mass of $\mathrm{Pu}^{239}$ during operation 


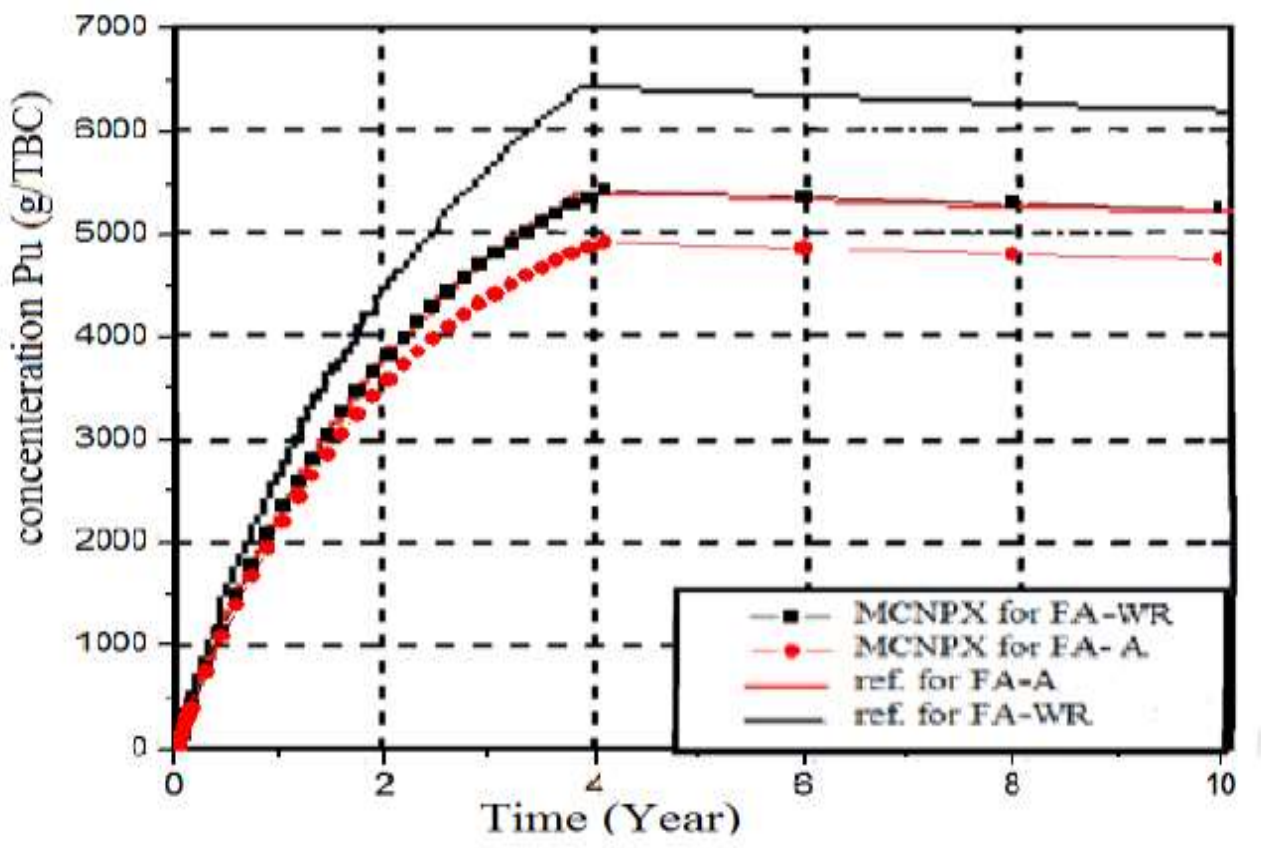

Figure 8: The mass of $\mathrm{Pu}$ - isotopes during operation and cooling

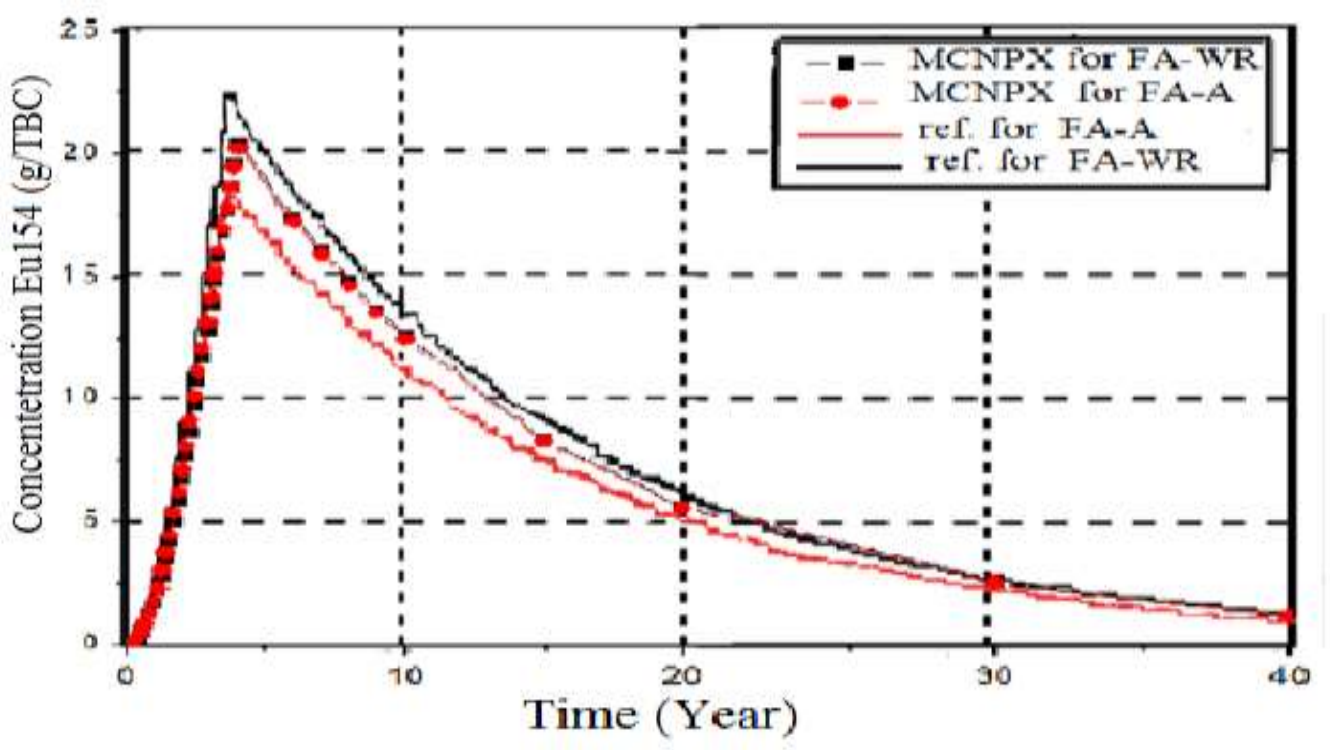

Figure 9: The mass of $\mathrm{Eu}^{154}$ during operation and cooling 
International Journal of Engineering Research And Advanced Technology, Vol.6, Issue 3, March-2020

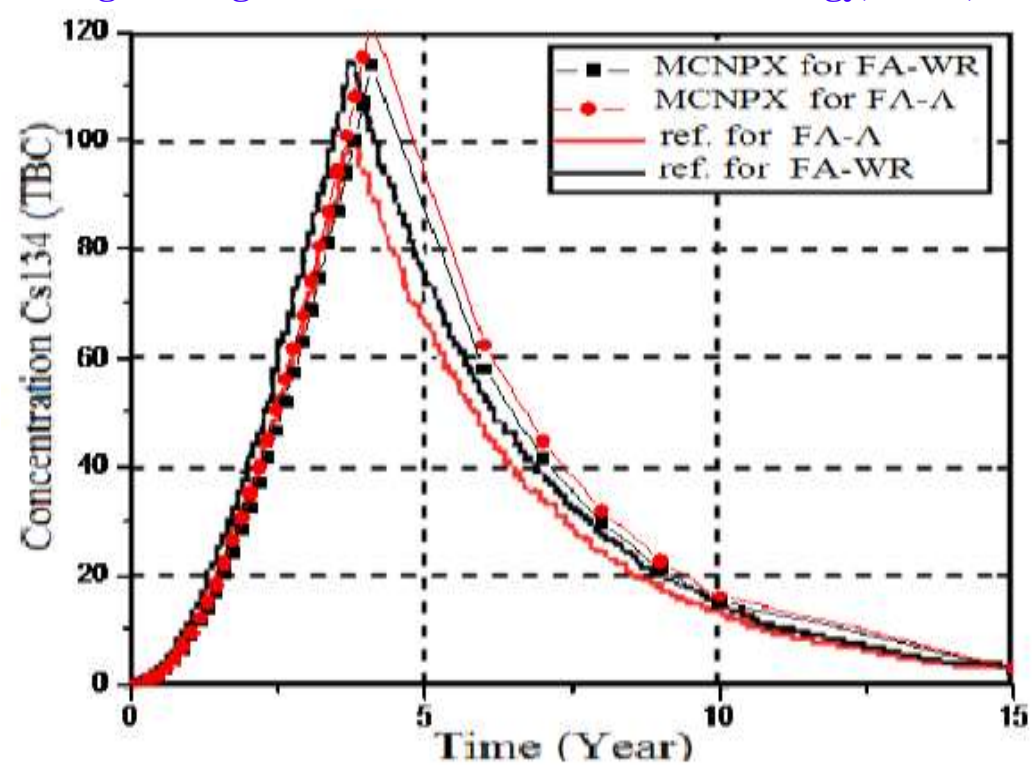

Figure 10: The mass of $\mathrm{Cs}^{134}$ during operation and cooling

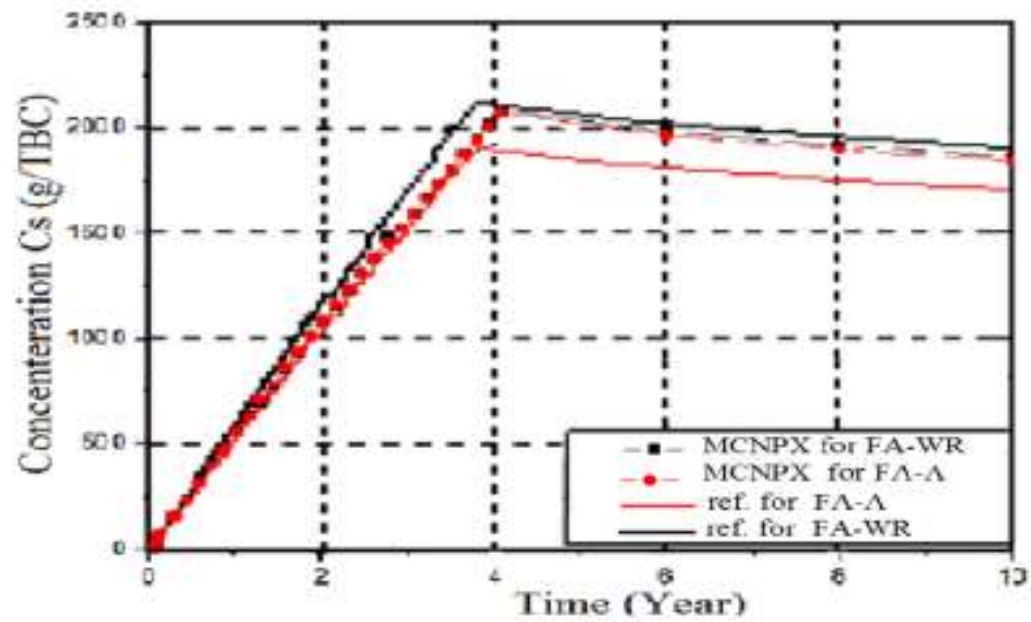

Figure 11: The mass of $\mathrm{Cs}$ - isotopes during operation and cooling

From figures 5-11 we can see that at low burnup there was a good agreement with SERPENT calculations for all isotopes in FA-A and FA-WR assemblies, while at high burnup, all Pu isotopes showed great discrepancies.

Figure 5 shows that depletion rate of $\mathrm{U}^{235}$ for FA-A assembly was larger than that for FA-WR assembly. Figure 6 shows excellent agreement between the buildup rate of $\mathrm{U}^{236}$ in the two assemblies when calculated by MCNPX, but less agreement when results were compared with those calculated by SERPENT code [5].

Only during the first 2 years of burnup for FA-WR, the buildup of ${ }^{239} \mathrm{Pu}$ and all other Pu isotopes as calculated by MCNPX code were almost equal to those calculated by SERPENT code. Otherwise, results of buildup of Pu as calculated by MCNPX were generally lower.

Figures 9-11 show that for $\mathrm{EU}^{154}, \mathrm{Cs}^{134}$ and all other $\mathrm{Cs}$ isotopes there was excellent agreement between concentration calculated by MCNPX and by SERPENT codes for operation and cooling. 


\section{CONCLUSIONS}

MCNPX and SERPENT codes gave very close estimation of $k_{\text {eff }}$ for fresh fuel calculations (initial $k_{\text {eff }}$ ) of both FA-A and FAWR assemblies, when the two models had similar geometry and structure. However, on burnup, the two codes gave significantly discrepancy between keff calculations. This may be due to difference in cross section libraries in the two codes, and/or difference in fission product yield in the two codes.

For FA-A assembly, as the burnup increases the $\mathrm{k}_{\text {eff }}$ initially increased, while for FA-WR assembly $\mathrm{k}_{\text {eff }}$ decreased rapidly till complete burnup of gadolinium.

Westinghouse FA-WR had lower value of the neutron multiplication factor $\mathrm{k}_{\mathrm{eff}}$ compared to FA-A company TVEL. Also the difference between the two values in the first three years was constant (approximately 0.03 ).

For both assemblies, MCNPX estimated $\mathrm{k}_{\text {eff }}$ were higher than those estimated by SERPENT code, with average difference of $5.2 \%$. Such discrepancy between the two codes on burnup, may be due to difference in cross sectional libraries, and/or difference in fission product inventory in both codes.

At the same burnup, spent FA-WR (Westinghouse) had less $k_{\text {eff }}$ than the TVS-A (TVEL). $k_{\text {eff }}$ for spent FA-WR (Westinghouse) was less by $\sim 1 \%$ than that for FA-A.

At low burnup there was a good agreement with SERPENT code calculations for all isotopes in FA-A and FA-WR assemblies, while at high burnup, all Pu isotopes showed great discrepancies.

Depletion rate of $\mathrm{U}^{235}$ for FA-A assembly was larger than that for FA-WR assembly. There was excellent agreement between the buildup rate of $\mathrm{U}^{236}$ in the two assemblies when calculated by MCNPX, but less agreement when results were compared with those calculated by SERPENT code [5].

Only during the first 2 years of burnup for FA-WR, the buildup of ${ }^{239} \mathrm{Pu}$ and all other Pu isotopes as calculated by MCNPX code were almost equal to those calculated by SERPENT code. Otherwise, results of buildup of Pu as calculated by MCNPX were generally lower.

For $\mathrm{EU}^{154}, \mathrm{Cs}^{134}$ and all other Cs isotopes there was excellent agreement between concentration calculated by MCNPX and by SERPENT codes for operation and cooling.

\section{REFERENCES}

[1] NEA/NSC/DOC10, 2002, "A VVER-1000 LEU and MOX Assembly Computational Benchmark", Nuclear Energy Agency, Organization for Economic Co-operation and Development.

[2] "MCNPX User's Manual”. Version 2.7.0, Los Alamos National Laboratory, LA-CP-11-00438, - 2011.

[3] Demin V. M., Abu Sondos M. A., and Smirnov A. D.," The Comparative Analysis of Neutrons Properties of the Nuclear Fuel Produced by the Westinghouse and the TVEL for the

Reactors VVER-1000 by Code SERPENT", AtomFuture-2017 XIII International Youth Scientific and Practical Conference "FUTURE OF ATOMIC ENERGY - Atom Future 2017"

Volume 2017.

[4] Y. Kovbasenko, "Comparative Analysis of VVER-1000 Westinghouse and TVEL Spent Fuel Capability", Universal Journal of Physics and Application 10(4): 105-109, 2016, DOI: 10.13189/ujpa.2016.100401.

[5] Y.Kovbasenko, Y.Bilodid, M.Yeremenko , "Comparative Analysis of Isotope Composition of VVER-1000 Spent Fuel Depending on Their Manufactory and Operation Conditions", 31 March 2015 (https://www.researchgate/publication/268385912) 